\title{
Reversible Dissociation and Ligand-Glutathione Exchange Reaction in Binuclear Cationic Tetranitrosyl Iron Complex with Penicillamine
}

\author{
Lidia Syrtsova, ${ }^{1}$ Natalia Sanina, ${ }^{1}$ Konstantin Lyssenko, ${ }^{2}$ \\ Evgeniy Kabachkov, ${ }^{1}$ Boris Psikha, ${ }^{1}$ Natal'ja Shkondina, ${ }^{1}$ Olesia Pokidova, ${ }^{1}$ \\ Alexander Kotelnikov, ${ }^{1}$ and Sergey Aldoshin ${ }^{1}$ \\ ${ }^{1}$ Institute of Problems of Chemical Physics of the Russian Academy of Sciences, Academician Semenov Avenue Chernogolovka, \\ Moscow Region 142432, Russia \\ ${ }^{2}$ A.N. Nesmeyanov Institute of Organoelement Compounds of RAS, 28 Vavilov Street, B-334, Moscow 119991, Russia \\ Correspondence should be addressed to Lidia Syrtsova; syrtsova@icp.ac.ru
}

Received 30 October 2013; Revised 15 December 2013; Accepted 8 January 2014; Published 25 March 2014

Academic Editor: Patrick Bednarski

Copyright (C) 2014 Lidia Syrtsova et al. This is an open access article distributed under the Creative Commons Attribution License, which permits unrestricted use, distribution, and reproduction in any medium, provided the original work is properly cited.

This paper describes a comparative study of the decomposition of two nitrosyl iron complexes (NICs) with penicillamine thiolic ligands $\left[\mathrm{Fe}_{2}\left(\mathrm{SC}_{5} \mathrm{H}_{11} \mathrm{NO}_{2}\right)_{2}(\mathrm{NO})_{4}\right] \mathrm{SO}_{4} \cdot 5 \mathrm{H}_{2} \mathrm{O}(\mathrm{I})$ and glutathione- (GSH-) ligands $\left[\mathrm{Fe}_{2}\left(\mathrm{SC}_{10} \mathrm{H}_{17} \mathrm{~N}_{3} \mathrm{O}_{6}\right)_{2}(\mathrm{NO})_{4}\right] \mathrm{SO}_{4} \cdot 2 \mathrm{H}_{2} \mathrm{O}$ (II), which spontaneously evolve to $\mathrm{NO}$ in aqueous medium. NO formation was measured by a sensor electrode and by spectrophotometric methods by measuring the formation of a hemoglobin- (Hb-) NO complex. The NO evolution reaction rate from (I) $k_{1}=(4.6 \pm 0.1) \cdot 10^{-3} \mathrm{~s}^{-1}$ and the elimination rate constant of the penicillamine ligand $k_{2}=(1.8 \pm 0.2) \cdot 10^{-3} \mathrm{~s}^{-1}$ at $25^{\circ} \mathrm{C}$ in $0.05 \mathrm{M}$ phosphate buffer, $\mathrm{pH}$ 7.0, was calculated using kinetic modeling based on the experimental data. Both reactions are reversible. Spectrophotometry and mass-spectrometry methods have firmly shown that the penicillamine ligand is exchanged for $\mathrm{GS}^{-}$during decomposition of $1.5 \cdot 10^{-4} \mathrm{M}(\mathrm{I})$ in the presence of $10^{-3} \mathrm{M} \mathrm{GSH}$, with $76 \%$ yield in $24 \mathrm{~h}$. As has been established, such behaviour is caused by the resistance of (II) to decomposition due to the higher affinity of iron to GSH in the complex. The discovered reaction may impede S-glutathionylation of the essential enzyme systems in the presence of (I) and is important for metabolism of NIC, connected with its antitumor activity.

\section{Introduction}

The intensive recent research in fundamental nitrogen monoxide (NO) chemistry as one of the necessary and universal regulators of cellular metabolism functions $[1,2]$ includes investigation of the properties of synthetic nonheme nitrosyl iron complexes (NICs) biomimetics of cellular NOintermediates [3-8]. NICs with functional sulfur-containing ligands represent a class of efficient NO-donating compounds [9] that can be used as a basis for new-generation medicinal products: efficient antitumour agents [10-12], original vasodilating medicinal products to treat acute coronary syndrome [13-16], and so forth. In the case of NO therapy it is especially important to study mechanisms of action of synthetic NICs and their biotransformation in vivo as potential NO-donating drugs (antitumor oncolytics, antihypertension, and antiaggregation action) and on functions of physiologically significant heme proteins. Intense studies of new exogenic donors of nitrogen monoxide (NO), carried out in recent years, have been directed to create new ways of producing NO. Clinical use of formulations that produce NO under physiological conditions has serious disadvantages related to their nitrate tolerance. Models of active centres of nonheme iron-sulfur proteins, NICs with functional sulphur-containing ligands synthesized by the Chemical Physics Institute of Russian Academy of Science $[17,18]$, spontaneously evolve NO in aqueous medium as a result of decomposition and appear to be prospective promedicines of a new generation [19, 20]. These are substances with dual drug-induced effect caused by biologically active thiols on the one hand and 
nitrogen monoxide on the other. They showed antitumour and cardiologic activity in preclinical testing.

We found that complex (I), the synthesis and composition of which are described $[14,21]$, evolves NO and penicillamine thiolyl upon decomposition [21].

The goal of this paper was the kinetic modeling of the decomposition of (I) to determine the elimination rate constant of penicillamine. The study also aimed to investigate the exchange reaction of the thiol ligands of (I) (as an efficient exogenic donor of NO [14]) for glutathione, as this is an important process for a possible exchange reaction of the NIC thiol ligand with biologically significant thiols in vivo. We have chosen reduced glutathione (GSH) to study ligand exchange reactions with (I). GSH is a water-soluble tripeptide consisting of amino acids: glutamic acid, cysteine, and glycine. GSH is the most commonly encountered nonprotein thiol in animal, and concentration in human tissues varies from 0.1 to $10 \mathrm{mM}$. The highest concentration is found in the liver, spleen, kidneys, crystalline lens, erythrocytes, and leucocytes. The functions of GSH are vital and versatile. Its cysteine thiol acts as a nucleophile in reactions with endogenous and exogenous compounds. Its main functions are (1) antioxidant, (2) cofactor of numerous cytoplasmic enzymes, and (3) thiolating agent at significant posttranslation modification of a number of cellular 3 proteins. The correlation between metabolism of GSH and such diseases such as cancer, neurodegenerative diseases, cystic fibrosis, HIV, and aging [22] has been established. Moreover GSH may promote S-glutathionylation of essential enzymes, receptors, structural proteins, transcription factors, and transport proteins [23].

\section{Experimental}

2.1. Materials. We used bovine Hb, Tris (Serva, Germany), acetonitrile LC-MS grade (Panreac, Spain), reduced Lglutathione, KI (ALDRICH, USA), $\mathrm{Na}_{2} \mathrm{HPO}_{4} \cdot 6 \mathrm{H}_{2} \mathrm{O}$ and $\mathrm{NaH}_{2} \mathrm{PO}_{4} \cdot \mathrm{H}_{2} \mathrm{O}$ (MP Biomedicals, Germany), $\mathrm{FeSO}_{4} \cdot 7 \mathrm{H}_{2} \mathrm{O}$, D-penicillamine (SIGMA, USA), Sephadex G-25 (Pharmacia, Sweden), and sodium dithionite (Merck, Germany). Water was purified by distillation in a Bi/Duplex distiller (Germany).

The synthesis, structure (CCDC 680286), and physicochemical data of (I) (Figure 1) have been described elsewhere $[14,21]$ and (II) was synthesized by a similar method [14]. Complex (I) has been obtained by reaction of ferrous sulphate(II) with an aqueous solution of D-penicillamine in the molar ratio $1: 3$. The reaction was performed using a standard vacuum line and Schlenk technology under argon. Previously, oxygen has been removed from the water by triple freezing and vacuum pumping. To a dry mixture, containing $0.42 \mathrm{~g}(1.5 \mathrm{mmol})$ of $\mathrm{FeSO}_{4} \cdot 7 \mathrm{H}_{2} \mathrm{O}$ and $0.68 \mathrm{~g}(4.5 \mathrm{mmol}) \mathrm{D}$ penicillamine were added $10 \mathrm{~mL}$ water, prepared as described above, and nitric oxide was passed through the resulting deep purple solution at room temperature. Fine red needles appeared on the walls of the reaction vessel after 10-12 min and gradually filled the entire volume of the solution. The mixture was kept for 3 days at $6-8^{\circ} \mathrm{C}$, filtered, and dried in vacuum under argon. Yield is $198 \mathrm{mg}$ (20\%). Complex (II) was prepared by the same synthetic route. Elemental analysis, Mössbauer, and EPR spectroscopy confirmed that the structure is similar to that of complex (I), but instead of the penicillamine thiol ligands two molecules GSH are present [21].

Elemental analysis of (I) and (II) polycrystals was conducted at the Multiaccess Analytic Centre of IPCP RAS.

IR-spectrum $\left(\mathrm{cm}^{-1}\right)$ of (I) and (II) was recorded on a PerkinElmer Spectrum 100X at room temperature. For (I) found: Fe, 15.60; C, 16.72; H, 4.50; N, 11.75; O, 38.02; S, 13.40\%. $\mathrm{Fe}_{2} \mathrm{C}_{10} \mathrm{H}_{32} \mathrm{~N}_{6} \mathrm{O}_{17} \mathrm{~S}_{3}$ required: Fe, 15.64; C, 16.76; H, 4.47; N, 11.73; O, 37.99; S, 13.41\%; IR: $v / \mathrm{cm}^{-1}=1771$ (s, NO); 1723 (s, NO). For (II) found: Fe, 11.40; C, 24.52; H, 3.91; N, 14.28; O, 36.02; S, 9.79\%. $\mathrm{Fe}_{2} \mathrm{C}_{20} \mathrm{H}_{38} \mathrm{~N}_{10} \mathrm{O}_{22} \mathrm{~S}_{3}$ required: Fe, 11.45; C, 24.54; H, 3.89; N, 14.31; O, 35.99; S, 9.82\%. IR: $\nu / \mathrm{cm}^{-1}=1771$ (s, NO); 1728 (s, NO).

2.2. Operation Technique in Inert Gas Atmosphere [24]. All procedures were carried out under nitrogen (high purity grade), which was additionally purified by passing through a column with a chromium-nickel catalyst. Nitrogen was purged to the magnetically stirred working solutions (buffer, water) solution for $30 \mathrm{~min}$. Hereinafter these solutions are named anaerobic. All the vessels used and quartz cells were sealed with Rubber Septa seals (Sigma, USA), which allowed one to introduce gases and other necessary components through a needle. A solution was transferred from one vessel to another using syringes with soldered needles or under excess nitrogen pressure using two needles connected with Teflon capillaries. Excess pressure was discharged through an additional needle capped with a Teflon capillary immersed into water. Cells and vessels with a volume of 4 and $5 \mathrm{~mL}$, respectively, containing weighed samples of the NICs or other reagents were purged with nitrogen through needles for $30 \mathrm{~min}$.

\subsection{Electrochemical Determination of the Concentration of} NO Evolved by (I) in Solutions under Examination. Amperometric sensor electrode amiNO-700 of in NO Nitric Oxide Measuring System (Innovative Instruments, Inc., USA) was used to measure the concentration of NO generated by (I). NO concentration in water solution was recorded for ca $500 \mathrm{~s}$ (using $0.2 \mathrm{~s}$ increments) with $\mathrm{NO}$-donor concentration in the solution equaling $0.4 \cdot 10^{-5} \mathrm{M}$. The experiments were conducted under nitrogen atmosphere. A standard water solution of $\mathrm{NaNO}_{2}(0.01 \mathrm{M})$, supplemented with an aqueous solution of $20 \mathrm{mg}$ of $\mathrm{KI}$ and $2 \mathrm{~mL}$ of $1 \mathrm{M} \mathrm{H}_{2} \mathrm{SO}_{4}$ (c.p.) in $18 \mathrm{~mL}$ of water as recommended by the manufacturer [25], was used to calibrate the electrochemical sensor. Sensor calibration and experiments were carried out at $25^{\circ} \mathrm{C}$ with intensive stirring. Phosphate buffer $0.05 \mathrm{M}$ pH 7.0 was used. Oxygen was removed from the buffer for experiments in anaerobic conditions by triple freezing and degassing in vacuum using standard Schlenk line technique, after which the buffer was stored up to $24 \mathrm{~h}$ in glass-stoppered flasks. To the sample of (I) in nitrogen-filled vessel $0.05 \mathrm{M}$ anaerobic phosphate buffer pH 7.0 in order to obtain (I) $6 \cdot 10^{-4} \mathrm{M}$ solution was added and 


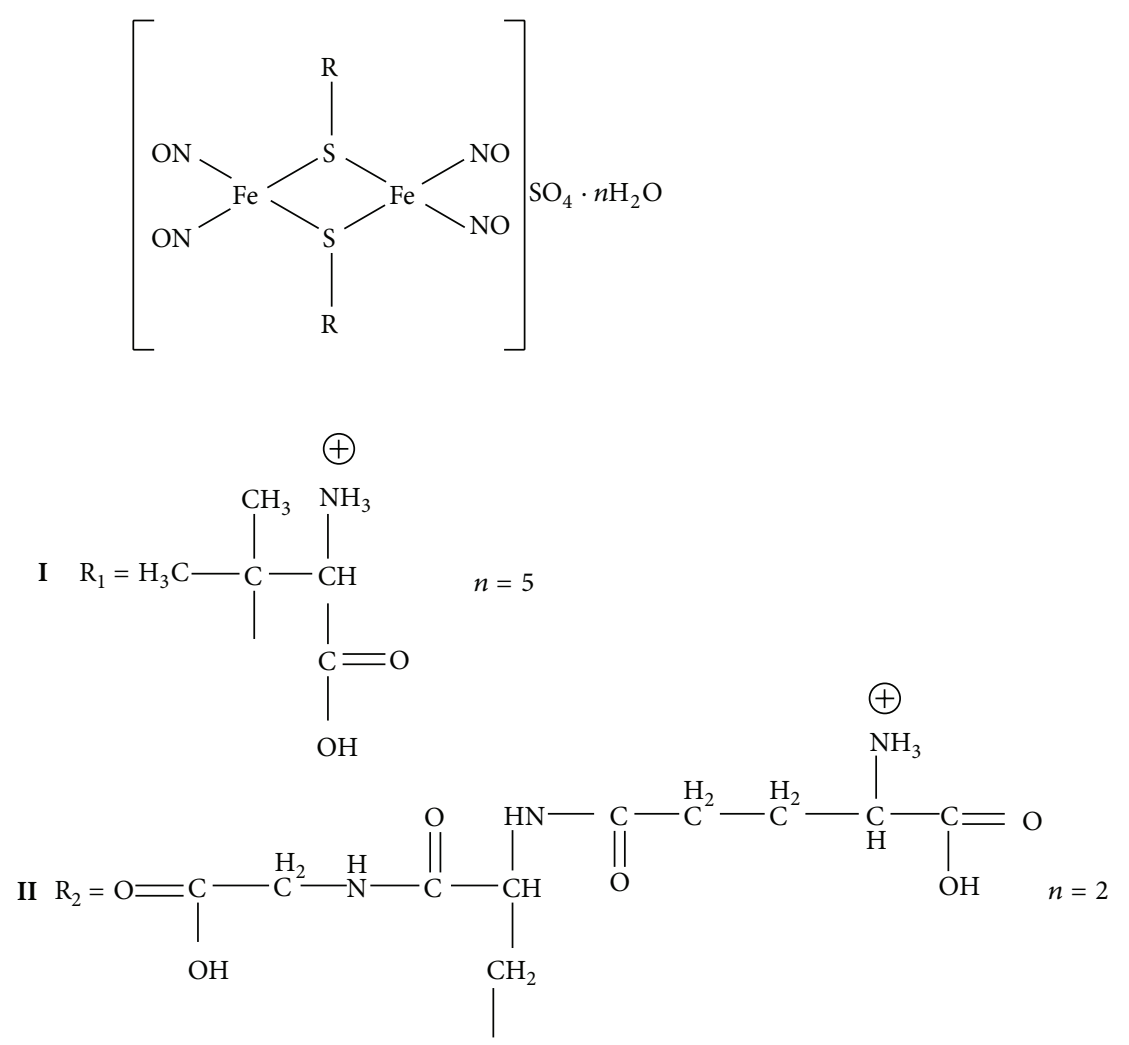

FIGURE 1: Chemical structures of the tetranitrosyl iron complexes (I) and (II) [14].

stirred for 10 to $15 \mathrm{~min}$ until complete dissolution of (I) shot. At the same time inert gas was transmitted for 30-40 minutes through the measuring electrochemical cell equipped with Rubber Septa (Sigma, USA) seals and connected to a thermostat, containing $49.5 \mathrm{~mL}$ of the prepared phosphate buffer with immersed thermal sensor and electrode. After this $0.5 \mathrm{~mL}$ of solution was removed from the vessel containing (I) solution and fed into the measuring cell though a rubber seal. Recording the formation of $\mathrm{NO}$ in the system was started at the same time.

2.4. Preparation of an $\mathrm{Hb}$ Solution. A homogeneous preparation of bovine $\mathrm{Hb}$ was obtained from bovine hemoglobin (MP Biomedicals, Germany), which was a mixture of methemoglobin (metHb) and oxygenated hemoglobin $\left(\mathrm{HbO}_{2}\right)$. A 0.05 Mphosphate buffer ( $\mathrm{pH} 7.0$ ) was used at all stages of $\mathrm{Hb}$ preparation and in all experiments with $\mathrm{Hb}$. To convert a mixture of metHb with $\mathrm{HbO}_{2}$ to $\mathrm{Hb}$, a column $2 \times 15 \mathrm{~cm}$ packed with Sephadex G-25 was prepared and transformed into the anaerobic state. For this purpose, $50 \mathrm{~mL}$ (volume of the column) of the anaerobic buffer and then $40 \mathrm{~mL}$ of the buffer containing sodium dithionite $\left(5 \mathrm{~mL}, 100 \mathrm{mg} \mathrm{mL}^{-1}\right.$ ) were passed through the column. The column was left to stand for $3 \mathrm{~min}$ and then dithionite was washed out with $50 \mathrm{~mL}$ the anaerobic buffer until a negative reaction for dithionite (with methyl viologen) was achieved. Commercial hemoglobin $(0.5 \mathrm{~g})$ was dissolved with stirring in the buffer $(5 \mathrm{~mL})$, nitrogen was purged for $30 \mathrm{~min}$ with stirring, and a solution of dithionite $\left(2 \mathrm{~mL}, 100 \mathrm{mg} \mathrm{mL}^{-1}\right)$ was added. The absorption spectrum of an aliquot of the solution showed that the whole mixture of metHb with $\mathrm{HbO}_{2}$ had been transformed into $\mathrm{Hb}$. Then excess dithionite and products of its decomposition were removed on a Sephadex G-25 column. A solution of $\mathrm{Hb}(5 \mathrm{~mL})$ with a concentration of $\sim 6 \cdot 10^{-4} \mathrm{M}$ was eluted. The solution of $\mathrm{Hb}$ was stored in the frozen state as aliquots in liquid nitrogen. Prior to use the $\mathrm{Hb}$ solution was thawn out in $5 \mathrm{~mL}$ flasks in a nitrogen flow. The indicator of purity and homogeneity of $\mathrm{Hb}$ was the ratio of molar absorption coefficients of all absorption maxima coinciding with published data.

2.5. Decomposition of Complex (I) or (II) at pH 7.0. The experiments were carried out using the same original $6 \cdot 10^{-4} \mathrm{M}$ solution of NIC. To the sample of NIC in a nitrogen-filled vessel $0.05 \mathrm{M}$ anaerobic Tris- $\mathrm{HCl}$ buffer $\mathrm{pH} 7.0$ in order to obtain a NIC $6 \cdot 10^{-4} \mathrm{M}$ solution was added, which was dissolved for $15 \mathrm{~min}$ and then frozen in liquid nitrogen in the shape of balls. For the purpose of experiments NIC was thawed under nitrogen flow for about 20 minutes until complete melting of the balls, and then solution aliquots of $0.75 \mathrm{~mL}$ were taken and inserted in a $4 \mathrm{~mL}$ anaerobic test cuvette (1 cm of optical path), containing $2.25 \mathrm{~mL}$ of $0.05 \mathrm{M}$ anaerobic buffer $\mathrm{pH} 7.0$ to achieve NIC final concentration of $1.5 \cdot 10^{-4} \mathrm{M}$. The reference cuvette contained $3 \mathrm{~mL}$ of buffer. The absorption spectra were recorded between $250-500 \mathrm{~nm}$ and 300-650 $\mathrm{nm}$ range at appropriate time intervals at $25^{\circ} \mathrm{C}$. 
2.6. Kinetics of (I) Interaction with GSH. The experiments were carried out under nitrogen atmosphere. A $6 \cdot 10^{-4} \mathrm{M}$ (I) solution, prepared as described above was used for experiments and $10^{-2} \mathrm{M}$ GSH solution in $0.1 \mathrm{M}$ Tris- $\mathrm{HCl}$ buffer pH 7.0. A $1.95 \mathrm{~mL}$ of anaerobic buffer and $0.75 \mathrm{~mL}$ of $6 \cdot 10^{-4} \mathrm{M}(\mathrm{I})$ solution were inserted in a $4 \mathrm{~mL}$ anaerobic test cuvette. The reaction was initiated by adding $0.3 \mathrm{~mL}$ of $10^{-2} \mathrm{M}$ GSH solution. The final concentration of (I) in test cuvette was $1.5 \cdot 10^{-4} \mathrm{M}$. The reference cuvette contained anaerobic buffer $\mathrm{pH} 7.0$ and (I) of the same concentration as in the test cuvette. The difference absorption spectra were registered at appropriate intervals, as indicated in the figures.

2.7. Kinetics of NIC Interaction ((I) or (II)) with $\mathrm{Hb}$. We used $6 \cdot 10^{-4} \mathrm{M}$ solutions of either (I) or (II) in $0.05 \mathrm{M}$ anaerobic Tris-HCl-buffer pH 7.0 after defrosting under nitrogen flow, prepared as described above. A $0.75 \mathrm{~mL}$ of NIC solution under nitrogen transferred to an anaerobic test cuvette and a $4 \mathrm{~mL}$ comparison cuvette, containing such quantity of $0.05 \mathrm{M}$ anaerobic buffer $\mathrm{pH} 7.0$, so that the resulting volume of reaction solution after introduction of approximately $0.11 \mathrm{~mL}$ of $\mathrm{Hb} 5.4 \cdot 10^{-4} \mathrm{M}$ solution into test cuvette would be $3.0 \mathrm{~mL}$. The reaction was initiated by adding $\mathrm{Hb}$ solution to the test cuvette to reach a $2 \cdot 10^{-5} \mathrm{M}$ concentration. Final concentration of NIC solution in the test cuvette and reference cuvette was $1.5 \cdot 10^{-4} \mathrm{M}$. Further the difference absorption spectra were registered at appropriate intervals, as indicated in the figures. Similarly the interaction of $\mathrm{Hb}$ with NIC $1.5 \cdot 10^{-4} \mathrm{M}$ in the presence of GSH $10^{-3} \mathrm{M}$ in anaerobic Tris- $\mathrm{HCl}$ buffer $\mathrm{pH} 7.0$ was studied. The buffer solution was inserted into anaerobic cuvettes $(1.84 \mathrm{~mL}$ and $1.95 \mathrm{~mL}$ in the test and reference cuvette, resp.), $0.75 \mathrm{~mL} \mathrm{NIC} 6 \cdot 10^{-4} \mathrm{M}$, and $0.3 \mathrm{~mL}$ of a $10^{-2} \mathrm{M}$ GSH solution in $0.1 \mathrm{M}$ Tris- $\mathrm{HCl}$ buffer $\mathrm{pH}$ 7.0. The reaction was initiated by adding the Hb solution in the test cuvette up to a $2 \cdot 10^{-5} \mathrm{M}$. Then the difference absorption spectra were registered at appropriate intervals, as indicated in the figures.

2.8. Absorption Spectra. Absorption spectra were recorded at $25^{\circ} \mathrm{C}$ using a Specord M-40 spectrophotometer equipped with an interface for computer-aided registration of spectra and thermostatic cuvette holder.

2.9. Amount of $\mathrm{Hb}$ and $\mathrm{HbNO}$. Amount of $\mathrm{Hb}$ and $\mathrm{HbNO}$ was evaluated spectrophotometrically. For this purpose absorption spectra were factored by components as described in the paper [17]. To determine the HbNO concentration, the absorption spectrum of the reaction system containing $\mathrm{Hb}$ and $\mathrm{HbNO}$ was deconvoluted to the components (spectra of $\mathrm{Hb}$ and $\mathrm{HbNO}$ ) by computer processing using the MathCad program. The solution should satisfy the criterion of the minimum of the sum of squared deviations of the experimental spectrum of the mixture from the calculated one:

$$
\sigma(\alpha, \beta)=\sum_{i}\left[D_{i}-F\left(D_{\mathrm{Hb}}, D_{\mathrm{HbNO}}, \alpha, \beta\right)\right]^{2},
$$

where $\sigma(\alpha, \beta)$ is the root mean square deviation; $D_{i}$ are the experimental data (absorbance) at a certain time moment;
$F$ is the desired function of the $D_{\mathrm{Hb}}, D_{\mathrm{HbNO}}, \alpha$, and $\beta$ values; $D_{\mathrm{Hb}}$ and $D_{\mathrm{HbNO}}$ are the initial absorbances of $\mathrm{Hb}$ and $\mathrm{HbNO}$, respectively; $\alpha$ and $\beta$ are the fractions of $\mathrm{HbNO}$ and $\mathrm{Hb}$, respectively. The calculation was performed in a wavelength region of $450-650 \mathrm{~nm}$ by 200 experimental points. In the whole series of experiments, the $\sigma(\alpha, \beta)$ value ranges from $2 \cdot 10^{-5}$ to $5 \cdot 10^{-6}$, indicating high quality of simulation of the absorption spectrum of the reaction mixture at each moment and high accuracy of determination of the $\mathrm{Hb}$ and $\mathrm{HbNO}$ concentrations.

2.10. Mass-Spectrometric Analysis. Mass-spectrometric analysis was carried out using a 2020 Shimadzu LC-MS instrument that includes a liquid chromatograph LC20 Prominence with matrix photo detector SPD-M20A $(200-800 \mathrm{~nm})$ and mass-selective quadrupole detector $(\mathrm{m} / z$ scanned mass range: 50-2000; ionization modes: DUIS/ ESI/APCI). Analysis conditions were as follows: ionization method-electrospray ionization, ESI-MS, sample input method-direct input, solvent-acetonitrile, incubation $\left(25^{\circ} \mathrm{C}\right)$, exposure mode-positive mode, or negative mode. Analysis samples were prepared under nitrogen atmosphere in $0.05 \mathrm{M}$ Tris-HCl-buffer $\mathrm{pH}$ 7.0. $2 \mathrm{~mL}$ vessels with a PTFE/Silicone/PTFE seal allow samples to be inserted with a syringe, blown with nitrogen for about 10 minutes before the sample was inserted.

2.11. ${ }^{57} \mathrm{Fe}$ Mössbauer Absorption Spectra of (I) and (II) Were Recorded on WissEl Operating in Constant Acceleration Mode. ${ }^{57} \mathrm{Co}$ in $\mathrm{Rh}$ matrix was used as the source. Spectra at low temperatures were measured using continuous flow helium cryostat CF-506 (Oxford Instruments) with controllable temperature. Mössbauer spectra were processed by the least square method assuming the Lorentzian form of the individual spectral components. ${ }^{57} \mathrm{Fe}$ Mössbauer spectra of polycrystals of (I) and (II) are a single doublets; with the parameters (quadrupole splitting $\Delta E_{Q}=0.913(4) \mathrm{mm} / \mathrm{s}$, isomer shift $\delta_{\mathrm{Fe}}=0.085(2) \mathrm{mm} / \mathrm{s}$, width of absorption lines $0.272(1) \mathrm{mm} / \mathrm{s}$ for (I) and $\Delta E_{\mathrm{Q}}=1.009(3) \mathrm{mm} / \mathrm{s}, \delta_{\mathrm{Fe}}=$ $0.076(2) \mathrm{mm} / \mathrm{s}$, width of absorption lines $0.250(1) \mathrm{mm} / \mathrm{s}$ for (II) at temperature $85 \mathrm{~K}$ ). They are similar to those for other complexes of " $\mu$-S" structural type. This indicates the structural equivalence of two iron atoms in (I) and (II).

2.12. The Proposed Reaction Scheme Describing Decomposition of (I) Was Considered for Kinetic Modelling. The values of the rate constants were determined using the least squares method on the basis of a numerical solution of the respective system of differential equations. The concentrations of NO and (I), determined by a sensor electrode or absorption spectra, were used as experimental data.

\section{Results and Discussion}

3.1. Decomposition of (I). Complex (I) (Figure 1) spontaneously evolves NO as a result of decomposition. This paper covers decomposition of (I) using two methods: (1) by direct determination of quantity of the released $\mathrm{NO}$ by means of 
sensor electrode and (2) spectrophotometrically by observing the absorption spectrum variation of (I).

3.1.1. Decomposition of (I) in 0.05 M Phosphate Buffer $p H$ 7.0. Measurement of NO Using a Sensor Electrode. Sensor electrode permits to measure total amount of $\mathrm{NO}$ in system, in solution, and adsorbed on the electrode: $x(t)=[\mathrm{NO}]+$ $\mathrm{NO}_{s} / V . V$ is the volume of reaction mixture in electrochemical cell equaling $50 \mathrm{~mL}$. [NO] is the $\mathrm{NO}$ concentration in the solution and $\mathrm{NO}_{s}$ is the number of $\mathrm{NO}$ gram-molecules on the electrode. Figure 2 represents the kinetic curve of space missing NO accumulation in a cell as recorded by a sensor electrode. Initial concentration of (I) is equal to $4 \cdot 10^{-6} \mathrm{M}$. It is seen that the curve rapidly reaches plateau, which is far less than $[(\mathbf{I})]_{0}$. It shows that evolution of NO is reversible and the reaction system is in a state of equilibrium:

$$
\text { (I) } \stackrel{\left(k_{1}, k_{-1}\right)}{\rightleftharpoons} \mathrm{P}_{1}+\mathrm{NO}
$$

NO binding to the electrode is the equilibrium process:

$$
\mathrm{NO} \stackrel{\left(k_{s}, k_{-s}\right)}{\rightleftharpoons} \mathrm{NO}_{s}
$$

Equation of NO accumulation is as follows:

$$
\frac{d x}{d t}=k_{1} \cdot[(\mathbf{I})]_{0}-k_{1} \cdot x-k_{n} \cdot x^{2}
$$

The required parameters are $k_{1}$ and $k_{n}=k_{-1} /\left(1+K_{s}\right)$, where $k_{s}$ is the equilibrium constant of binding NO to the electrode. Parameter $k_{n}$ describes the reversibility of (I) decomposition in the presence of NO binding to the electrode. As the NO amount, adsorbed on the electrode is much less than the amount of NO in solution (it is the property of this electrode), $K_{s} \ll 1, k_{n} \approx k_{-1}$. As a result of approximation of the experimental curve with (4) the following values of required rate constants have been obtained: $k_{1}=(4.6 \pm 0.1) \cdot 10^{-3} \mathrm{~s}^{-1}$; $k_{n}=(9.7 \pm 0.2) \cdot 10^{-3} \mathrm{M}^{-1} \cdot \mathrm{s}^{-1}$ (Figure 2).

\subsubsection{Decomposition of (I) in 0.05 M Phosphate Buffer pH 7.0.} Measurement of (I) Concentration Using Spectrophotometry. The change of absorption spectra of (I) was monitored during this experiment. Absorption spectra within 450 to $650 \mathrm{~nm}$ range were recorded at 10-15 min intervals and, keeping in mind the molar absorption extinction of (I) in the maximum absorption point in this range- $450 \mathrm{~nm}$ (Figure 3), we built kinetic relations of absorbance change (decrease) substrate concentration (Figure 4). It has been established that in anaerobic conditions the rate of decomposition increases subject to increase in the concentration of (I) (Figure 4). However, in case of (I) the change in absorption spectra takes places not only due to NO-group evolution, but by elimination of penicillamine ligand (L). Assuming that ligand is eliminated both from $(\mathrm{I})$ and $\mathrm{P}_{1}$ product, resulting after $\mathrm{NO}$

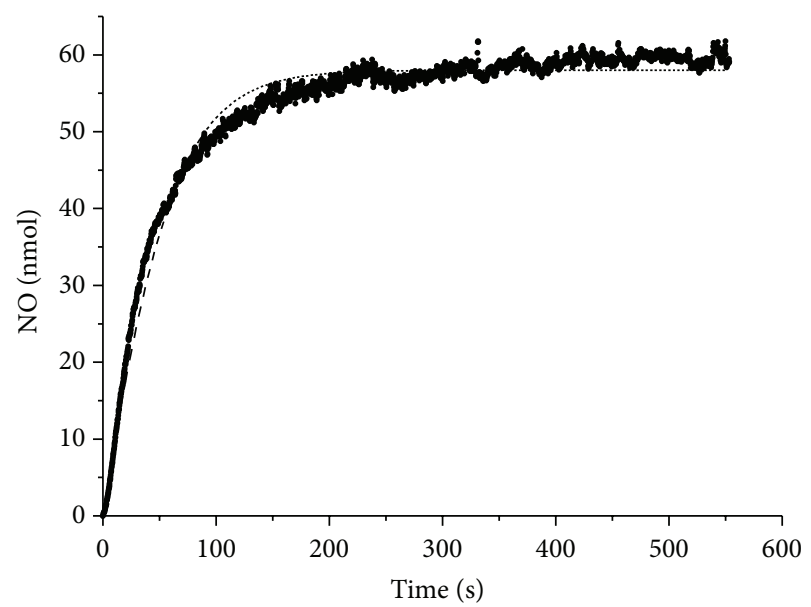

FIGURE 2: Kinetic curve of the accumulation of NO in solution (the measurements were carried out by a sensor electrode) in the course of the decomposition of (I) $4 \cdot 10^{-6} \mathrm{M}$ in 0.05 phosphate buffer $\mathrm{pH}$ 7.0 under anaerobic conditions at $25^{\circ} \mathrm{C}$. The dashed line represents the approximation by $d x / d t=k_{1} \cdot[(\mathbf{I})]_{0}-k_{1} \cdot x-k_{n} \cdot x^{2}$. (I) is the complex $\left[\mathrm{Fe}_{2}\left(\mathrm{SC}_{5} \mathrm{H}_{11} \mathrm{NO}_{2}\right)_{2}(\mathrm{NO})_{4}\right] \mathrm{SO}_{4} \cdot 5 \mathrm{H}_{2} \mathrm{O}$.

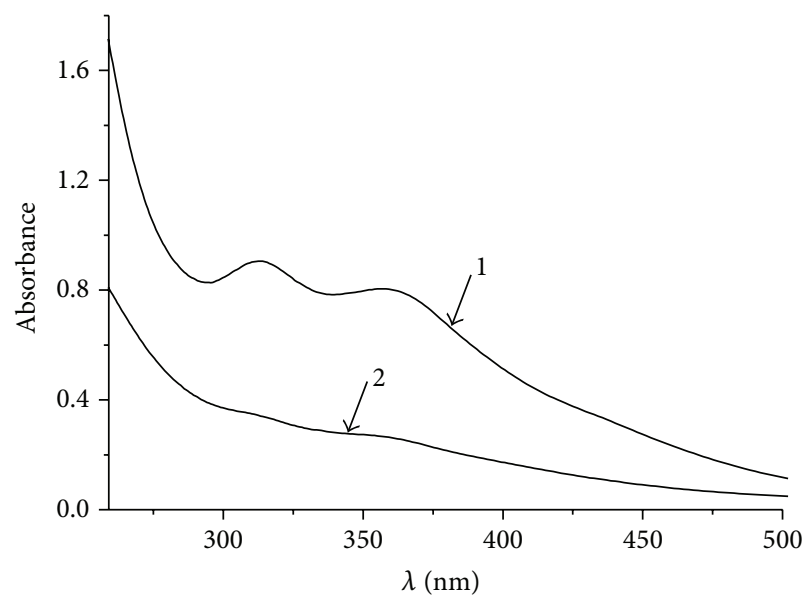

FIgUre 3: Spectra of $10^{-4} \mathrm{M}$ (I) in $0.05 \mathrm{M}$ phosphate buffer, pH 7.0 makeup (1) and after 18 hours at $25^{\circ} \mathrm{C}(2)$. Extinction at $\lambda=312 \mathrm{~nm}$ is equal to $9.1 \cdot 10^{3} \mathrm{M}^{-1} \mathrm{~cm}^{-1}$ and $2.6 \cdot 10^{3} \mathrm{M}^{-1} \mathrm{~cm}^{-1}$ at $450 \mathrm{~nm}$. (I) is the complex $\left[\mathrm{Fe}_{2}\left(\mathrm{SC}_{5} \mathrm{H}_{11} \mathrm{NO}_{2}\right)_{2}(\mathrm{NO})_{4}\right] \mathrm{SO}_{4} \cdot 5 \mathrm{H}_{2} \mathrm{O}$.

evolution from (I), the following reaction mechanism can be suggested:

$$
\begin{gathered}
(\mathrm{I}) \stackrel{\left(k_{1}, k_{-1}\right)}{\rightleftharpoons} \mathrm{P}_{1}+\mathrm{NO}, \quad \mathrm{P}_{1} \stackrel{\left(k_{2}, k_{-2}\right)}{\rightleftharpoons} \mathrm{P}_{2}+\mathrm{L}, \\
(\mathrm{I}) \stackrel{\left(k_{3}\right)}{\rightleftharpoons} \mathrm{P}_{3}+\mathrm{L}
\end{gathered}
$$

The results obtained with sensor electrode suggest that $k_{1}=$ $(4.6 \pm 0.1) \cdot 10^{-3} \mathrm{~s}^{-1} ; k_{n}=(9.7 \pm 0.2) \cdot 10^{3} \mathrm{M}^{-1} \cdot \mathrm{s}^{-1}$. Required parameters are $k_{2}, k_{-2}, k_{3}$. (I) and $\mathrm{P}_{1}$ are spectrophotometrically indistinguishable, so experimentally measured value $x(t)=[(\mathbf{I})]+\left[\mathrm{P}_{1}\right]$. 


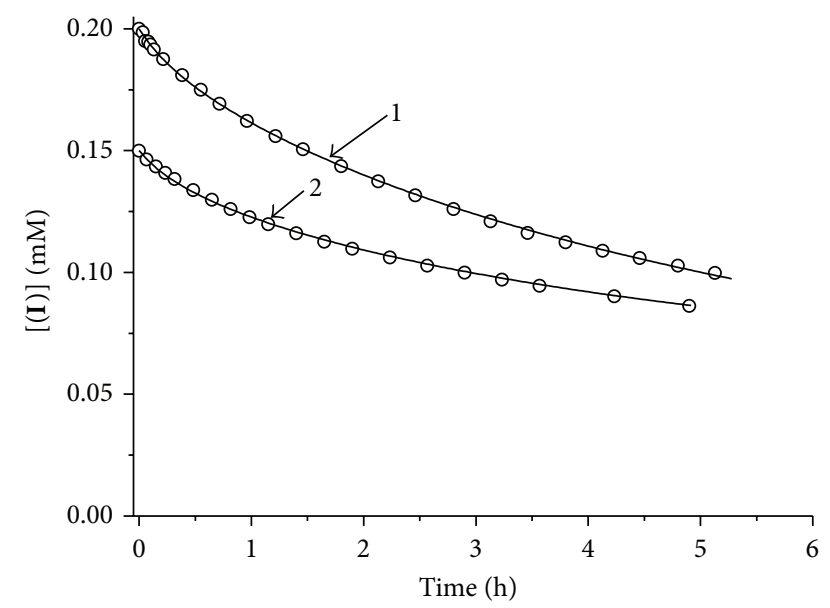

Figure 4: Kinetics of (I) decomposition in $0.05 \mathrm{M}$ phosphate buffer, $\mathrm{pH} 7.0$ at $25^{\circ} \mathrm{C}$. Starting (I) concentrations are equal to $1.5 \cdot 10^{-4}(1)$ and $2 \cdot 10^{-4}(2) \mathrm{M}$. Circles are the experimental data. Solid lines are the simulated curves, corresponding to the experimental points. Simulation was made by means of a system of differential equations (6). (I) is the complex $\left[\mathrm{Fe}_{2}\left(\mathrm{SC}_{5} \mathrm{H}_{11} \mathrm{NO}_{2}\right)_{2}(\mathrm{NO})_{4}\right] \mathrm{SO}_{4} \cdot 5 \mathrm{H}_{2} \mathrm{O}$.

TABLE 1: Results of kinetic modelling calculations (denote the rate constants of the reactions that are given in the text).

\begin{tabular}{lccc}
\hline$[(\mathrm{I})]_{0} \cdot 10^{4}, \mathrm{M}$ & $k_{2} \cdot 10^{3}, \mathrm{~s}^{-1}$ & $k_{-2}, \mathrm{M}^{-1} \cdot \mathrm{s}^{-1}$ & $k_{3} \cdot 10^{5}, \mathrm{~s}^{-1}$ \\
\hline 1 & 1.9 & 0.1 & 0.8 \\
1.5 & 1.7 & 0.2 & 0.9 \\
2.0 & 1.8 & 0.1 & 1.8 \\
\hline
\end{tabular}

The system of equations, corresponding to scheme of reactions:

$$
\begin{gathered}
\frac{d[\mathbf{I}]}{d t}=-k_{1}[\mathbf{I}]+k_{-1}\left[\mathrm{P}_{1}\right][\mathrm{NO}]-k_{3}[\mathbf{I}] \\
\frac{d[\mathrm{NO}]}{d t}=k_{1}[\mathbf{I}]-k_{-1}\left[\mathrm{P}_{1}\right][\mathrm{NO}] \\
\frac{d\left[\mathrm{P}_{1}\right]}{d t}=k_{1}[\mathbf{I}]-k_{-1}\left[\mathrm{P}_{1}\right][\mathrm{NO}]-k_{2}\left[\mathrm{P}_{1}\right]+k_{-2}\left[\mathrm{P}_{2}\right][\mathrm{L}] \\
\frac{d\left[\mathrm{P}_{2}\right]}{d t}=k_{2}\left[\mathrm{P}_{1}\right]-k_{-2}\left[\mathrm{P}_{2}\right][\mathrm{L}] \\
\frac{d[\mathrm{~L}]}{d t}=k_{2}\left[\mathrm{P}_{1}\right]-k_{-2}\left[\mathrm{P}_{2}\right][\mathrm{L}]+k_{3}[\mathbf{I}] .
\end{gathered}
$$

By solution of system of equations using the kinetic modelling method, the values of required rate constants (Table 1) have been found that satisfactorily describe the curves of Figure 4 (approximation is shown in solid lines). Based on Table $1 k_{2}$ (reaction rate of penicillamine ligand eliminated from $(\mathbf{I})$ ) is determined with good accuracy. As experimental data error is $\pm 10 \%$, the value of $k_{2}=(1.8 \pm 0.2) \cdot 10^{-3} \mathrm{~s}^{-1}$.

\begin{tabular}{|c|c|c|c|}
\hline $\begin{array}{l}\text { Figure } \\
\text { number }\end{array}$ & NIC & Process & $k, \mathrm{~s}^{-1}$ \\
\hline Figure 5 & (II) & Decomposition & $(3.8 \pm 0.4) \cdot 10^{-5}$ \\
\hline Figure 6 & (II) & Interaction with $\mathrm{Hb}$ & $(2.6 \pm 0.3) \cdot 10^{-5}$ \\
\hline Figure 6 & (I) & Interaction with $\mathrm{Hb}$ and $\mathrm{GSH}$ & $(1.5 \pm 0.15) \cdot 10^{-4}$ \\
\hline Figure 6 & (I) & Interaction with $\mathrm{Hb}$ & $(6.4 \pm 0.6) \cdot 10^{-4}$ \\
\hline Figure 7 & (I) & Decomposition & $(1.3 \pm 0.1) \cdot 10^{-4}$ \\
\hline Figure 8 & (I) & Interaction with GSH & $(6.9 \pm 0.7) \cdot 10^{-5}$ \\
\hline
\end{tabular}

3.2. Ligand Exchange in (I) for GSH Based on Spectrophotometric Data. In this paper we investigated the interaction of (I) with GSH. In addition to the importance of GSH, this
TABLE 2: Results of kinetic experiments (average of three).

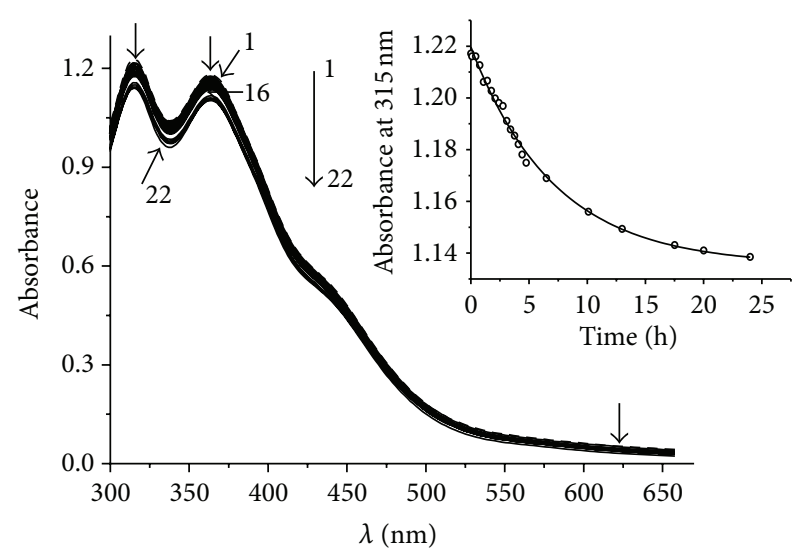

FIGURE 5: Kinetics of change of absorption spectrum of (II) (1.5 . $\left.10^{-4} \mathrm{M}\right)$ : spectra were registered at $30 \mathrm{~s}(1), 5$ (2) min after start of reaction. Spectra 3-16 were registered further with interval $20 \mathrm{~min}$. Spectra 17-22 were registered at 6.5 (17), 10.1 (18), 13 (19), $17.5(20), 20(21)$, and $24(22) \mathrm{h}$ after start of reaction. Conditions of reaction: $25^{\circ} \mathrm{C}$, solvent is $0.05 \mathrm{M}$ Tris- $\mathrm{HCl}$ buffer, and $\mathrm{pH}$ 7.0. Spectra 1-22 have 2 maxima: $\lambda_{1}=315 \mathrm{~nm}$ and $\lambda_{2}=365 \mathrm{~nm}$; $\varepsilon_{315 \mathrm{~nm}}$ is equal to $8.2 \cdot 10^{3} \mathrm{M}^{-1} \cdot \mathrm{cm}^{-1}$. The inset shows kinetics of (II) $\left(1.5 \cdot 10^{-4} \mathrm{M}\right)$ decomposition in $0.05 \mathrm{M}$ Tris-HCl-buffer $\mathrm{pH} 7.0$ at $25^{\circ} \mathrm{C}$ (for the experimental data shown on this figure). Circles are experimental data. Approximation (theoretical curve) was made by means of $y(t)=y_{o}+A \cdot e^{-k t}$. (II) is the complex $\left[\mathrm{Fe}_{2}\left(\mathrm{SC}_{10} \mathrm{H}_{17} \mathrm{~N}_{3} \mathrm{O}_{6}\right)_{2}(\mathrm{NO})_{4}\right] \mathrm{SO}_{4} \cdot 2 \mathrm{H}_{2} \mathrm{O}$.

choice is also explained by the fact that we intended to obtain an NIC product of the same structure as (I) (Figure 1) but with GSH as the thiolic ligand, bis-(glutathione-2-thiolate) tetranitrosyl diiron (II). According to our data, (II) proved to be extremely resistant to decomposition (Figure 5). We used $0.05 \mathrm{M}$ Tris-HCl buffer as a solvent due to the simultaneous mass-spectrometric analysis of samples being conducted. In the phosphate buffer, where NIC was dissolved earlier [17], the phosphate spectrum superimposed the test sample's spectrum in the profile of multiple peaks. All investigations were conducted under nitrogen atmosphere, as NO promptly interacts with $\mathrm{O}_{2}$, producing nitrogen oxides with rate constant $2 \cdot 10^{6}\left(\mathrm{M}^{-1}\right)^{2} \cdot \mathrm{s}^{-1}$ at $25^{\circ} \mathrm{C}$ [26]. Figure 5 shows data concerning the change in absorption spectrum of (II) in solution, whereas Figure 6 (curve 1) shows the kinetics of NO evolution by formation of $\mathrm{HbNO}$.

For comparison, the same investigation was carried out with (I) (Figure 7, Figure 6 curve 3). Hb demonstrates 
TABLE 3: The results of mass spectrometry (Figure 9).

\begin{tabular}{|c|c|c|c|}
\hline $\begin{array}{l}\text { Ion mass singly } \\
\text { charged, } m / z\end{array}$ & Ion type & $\begin{array}{c}\text { Formula for } \mathrm{M} \text {, } \\
\text { subunit or sequence }\end{array}$ & Origin and other comments \\
\hline 308 & {$[\mathrm{M}+\mathrm{H}]^{+}$} & GSH & Glutathione, $\mathrm{C}_{10} \mathrm{O}_{6} \mathrm{~N}_{3} \mathrm{SH}_{17}$ \\
\hline 477 & {$[\mathrm{M}-\mathrm{GSH}-2 \mathrm{NO}+\mathrm{H}]^{+}$} & {$\left[\mathrm{Fe}_{2}(\mathrm{GSH})_{2}(\mathrm{NO})_{4}\right]$} & Decomposition of (II) \\
\hline 538 & {$[\mathrm{M}-\mathrm{GSH}+\mathrm{H}]^{+}$} & {$\left[\mathrm{Fe}_{2}(\mathrm{GSH})_{2}(\mathrm{NO})_{4}\right]$} & Decomposition of (II) \\
\hline 613 & {$[\mathrm{M}+\mathrm{H}]^{+}$} & GS-SG & Oxidized form of glutathione \\
\hline 845 & {$[\mathrm{M}+\mathrm{H}]^{+}$} & {$\left[\mathrm{Fe}_{2}(\mathrm{GSH})_{2}(\mathrm{NO})_{4}\right]$} & Cation of (II) \\
\hline 867 & {$[\mathrm{M}+\mathrm{Na}]^{+}$} & {$\left[\mathrm{Fe}_{2}(\mathrm{GSH})_{2}(\mathrm{NO})_{4}\right]$} & Cation of $(\mathbf{I I})-\mathrm{Na}^{+}$ \\
\hline
\end{tabular}

(II) is the complex $\left[\mathrm{Fe}_{2}\left(\mathrm{SC}_{10} \mathrm{H}_{17} \mathrm{~N}_{3} \mathrm{O}_{6}\right)_{2}(\mathrm{NO})_{4}\right] \mathrm{SO}_{4} \cdot 2 \mathrm{H}_{2} \mathrm{O}$.

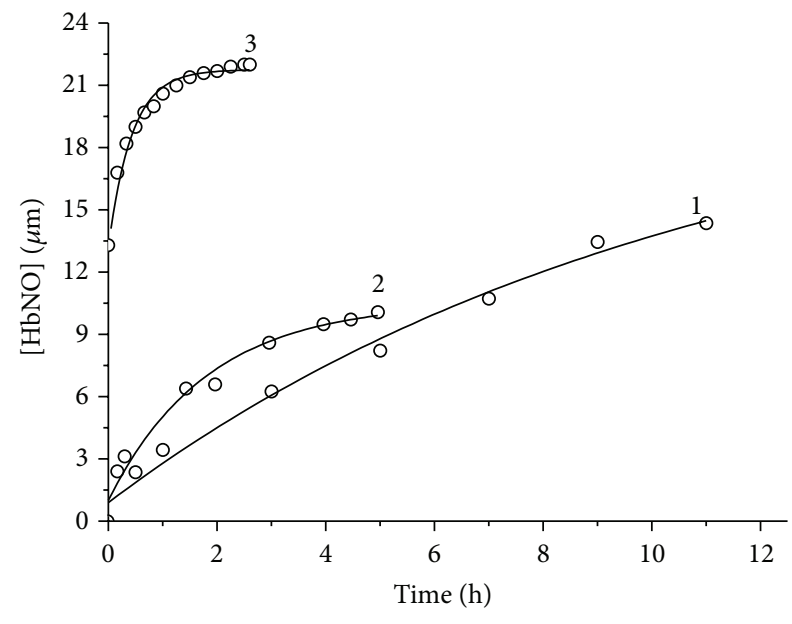

FIGURE 6: (1) Kinetics of HbNO formation at interaction of (II) with $\mathrm{Hb}$ on the base of the experimental data shown in (a). (2) Kinetics of $\mathrm{HbNO}$ formation at interaction of (I) with GSH in $\mathrm{Hb}$ presence. $\mathrm{Hb}$ on the base of the experimental data shown in (b). (3) Kinetics of $\mathrm{HbNO}$ formation in the interaction of (I) with $\mathrm{Hb}$, the experimental data shown in (c). Circles are the experimental data. Solid line is the approximation by means of $y(t)=y_{o}+A \cdot(1-$ $e^{-k t}$ ). (Figures a, b, and $\mathrm{c}$ are in Supplementary Materials available online at http://dx.doi.org/10.1155/2014/641407). (II) is the complex $\left[\mathrm{Fe}_{2}\left(\mathrm{SC}_{10} \mathrm{H}_{17} \mathrm{~N}_{3} \mathrm{O}_{6}\right)_{2}(\mathrm{NO})_{4}\right] \mathrm{SO}_{4} \cdot 2 \mathrm{H}_{2} \mathrm{O}$.

a specific absorption spectrum that alters as NO is attached. Therefore, as described in papers [14, 17] for this class of NO donors, evolution of NO can be traced by formation of HbNO. Since all NICs absorb in the visible spectrum, the experiment recorded difference absorption spectra of the buffer and test system with $\mathrm{Hb}$ containing NIC in equal concentrations. The composition of reaction mixtures is described in Experimental. By recording $\mathrm{HbNO}$ accumulation and fractioning of absorption spectra into components, we measured the kinetics of $\mathrm{HbNO}$ formation (Figure 6). Using the following equation: $y(t)=y_{o}+A\left(1-e^{-k t}\right)$, we obtained effective first-degree rate constants $(k)$ for these reactions (given in Table 2). It has been established that NO is evolved from (II) almost 25 times more slowly than from (I) (Table 2, Figure 6), while absorption spectrum of (II) decreases 3.4 times more slowly as compared to that of (I) (Figures 5 and 7). In the reaction scheme containing (I) and
GSH (Figure 8) the absorption spectrum, the parameters of which match the absorption spectra of (II) (Figure 5), grew. Maximum absorption increase took place within 24 hours. At the same time the concentration of the resulting (II) (taking into account that $\varepsilon$ at $315 \mathrm{~nm}$ is equal to $8.18 \cdot 10^{3} \mathrm{M}^{-1} \mathrm{~cm}^{-1}$, Figure 5) was $1.15 \cdot 10^{-4} \mathrm{M}$, while concentration of the original (I) is $1.5 \cdot 10^{-4} \mathrm{M}$; that is, the output is $76 \%$. Output cannot reach $100 \%$ because the (II) decay takes place in parallel and output of (II) should be determined by the ratio of the equilibrium constants of (I) and (II). When $\mathrm{Hb}$ was present in the (I)-GSH system, $\mathrm{HbNO}$ accumulated with $\kappa$ equal $1.5 \cdot 10^{-4} \mathrm{~s}^{-1}$ (Figures 6 , curve 2); that is, NO output rate was somewhere between (I)-Hb (Figure 6 curve 3 ) and (II)-Hb (Figures 6, curve 1) system as NO evolved both from (I) and (II).

As seen in Figure 6, curve 3, there are some traces of $\mathrm{HbNO}$ (the reaction was initiated by adding $\mathrm{Hb}$ ) at time zero, with initial concentration for (I) being higher. This can be explained by the fact that dissolution of NIC (see Experimental) took a certain time, $\sim 15$ minutes. Partial decomposition with release of $\mathrm{NO}$ took place during this period of time, and then newly formed $\mathrm{HbNO}$ was detected at the first recording of the absorption spectrum. Original NIC solution $\left(6 \cdot 10^{-4} \mathrm{M}\right)$ was frozen to ensure an NIC solution of the same concentration was used.

3.3. Mass-Spectrometry Analysis. Mass-spectral analysis of the reaction mixture of (I) with GSH (Figure 8, Table 3) was performed. In the course of analyzing the products of the interaction of (I) with GSH (Figure 8) after a $24 \mathrm{~h}$ incubation at $25^{\circ} \mathrm{C}$, which corresponded to maximum output of the product of the interaction of these compounds (Figure 8), the (II) cation was detected. Moreover, the spectrum shows a certain amount of the products of decomposition of (II) and also the oxidized form of GSH, GS-SG. Thus, the results of mass-spectral analysis of reaction mixture of (I) with GSH qualitatively correspond to the data obtained in the spectrophotometric study.

\section{Conclusions}

This paper shows for the first time that NIC with a thiol ligands of penicillamine $\left[\mathrm{Fe}_{2}\left(\mathrm{SC}_{5} \mathrm{H}_{11} \mathrm{NO}_{2}\right)_{2}(\mathrm{NO})_{4}\right] \mathrm{SO}_{4} \cdot 5 \mathrm{H}_{2} \mathrm{O}$ (I) reversibly releases both $\mathrm{NO}$ and thiol ligand in aqueous 


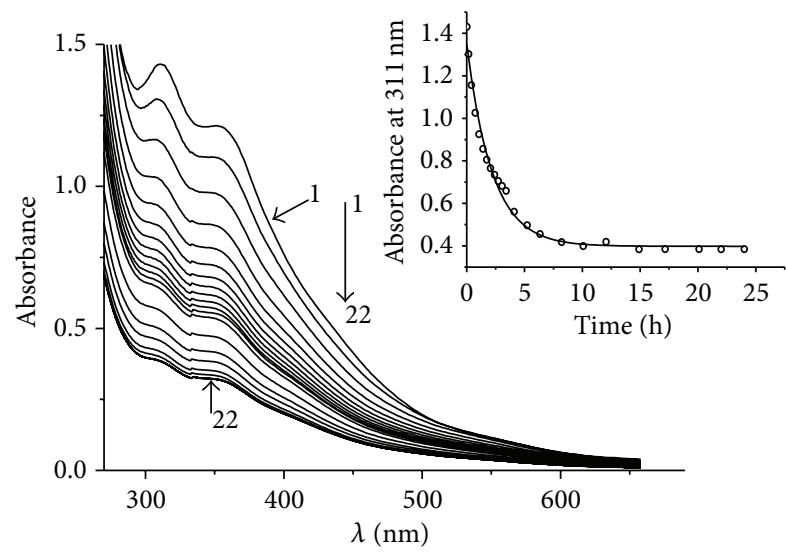

FIGURE 7: Kinetics of change of absorption spectrum of (I) (1.5 . $\left.10^{-4} \mathrm{M}\right)$ : spectra were registered at $30 \mathrm{~s}(1), 9 \mathrm{~min}(2)$ after start of reaction. Spectra 3-12 were registered further with interval of $20 \mathrm{~min}$. Spectra 13-22 were registered at 4.1 (13), 5.2 (14), 6.3 (15), 8.2 (16), 10 (17), 14.9 (18), 17.1 (19), 20.1 (20), 22 (21), and 24 (22) h after start of reaction. Conditions of reaction: $25^{\circ} \mathrm{C}$ solvent is $0.05 \mathrm{M}$ Tris- $\mathrm{HCl}$ buffer, $\mathrm{pH}$ 7.0. Spectra 1-22 have 2 maxima: $\lambda_{1}=311$ нм и $\lambda_{2}=353 \mathrm{Hм}$. The inset shows kinetics of the decomposition of (I) $\left(1.5 \cdot 10^{-4} \mathrm{M}\right)$ in $0.05 \mathrm{M}$ Tris-HCl-buffer $\mathrm{pH} 7.0$ at $25^{\circ} \mathrm{C}$ (for the experimental data shown on this figure). Circles are the experimental data.

medium. Rate constants of these first-degree reactions were determined. Decomposition equilibrium of (I) apparently shifts as NO is consumed in reactions that are required as universal regulators of cellular metabolism functions $[1,2]$. Convincing evidence shows that penicillamine ligands of NIC (I) in solution in the presence of GSH replaces the original thiolic ligands with GS-, thus forming new NIC, (II), which is quite decomposition-resistant and shown here. We assume that this may influence the important role of (I) in biotransformations, connected with antitumour activity. The strength of the thiol-Fe bond in (II) is impressive. It can probably be explained by the fact that GSH is a tripeptide and is bonded with the S-group of cysteine, which is located between glutamic acid and glycine. These two amino acids likely "shield" the Fe-S bond in (II) from attacks by thiol and water.

\section{Abbreviations}

(I): Complex $\left[\mathrm{Fe}_{2}\left(\mathrm{SC}_{5} \mathrm{H}_{11} \mathrm{NO}_{2}\right)_{2}(\mathrm{NO})_{4}\right] \mathrm{SO}_{4} \cdot 5 \mathrm{H}_{2} \mathrm{O}$

(II): Vomplex $\left[\mathrm{Fe}_{2}\left(\mathrm{SC}_{10} \mathrm{H}_{17} \mathrm{~N}_{3} \mathrm{O}_{6}\right)_{2}(\mathrm{NO})_{4}\right] \mathrm{SO}_{4} \cdot 2 \mathrm{H}_{2} \mathrm{O}$

NIC: Nitrosyl iron complex.

\section{Conflict of Interests}

The authors declare that there is no conflict of interests regarding the publication of this paper.

\section{Acknowledgment}

This study was financially supported by the RFBR (Grant no. 13-03-00549). The authors wish to thank Dr. A. V. Chudinov for the preparation of the program of computer processing of

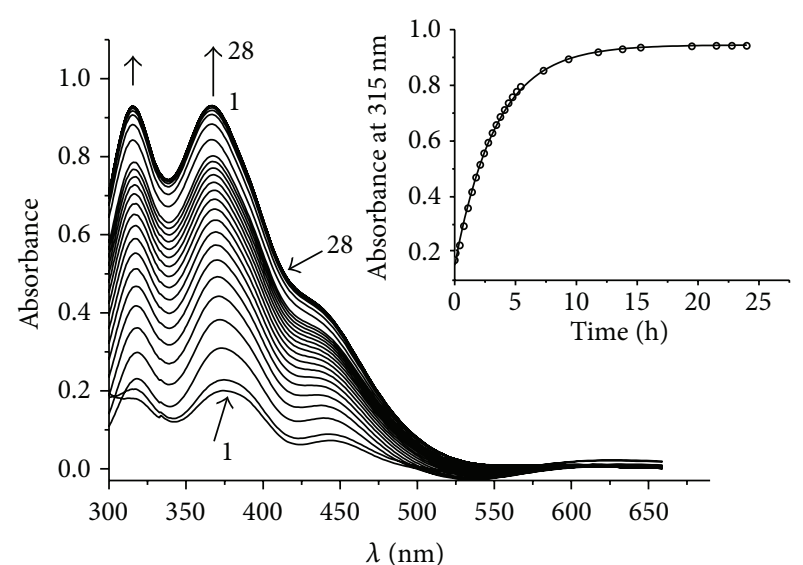

FIGURE 8: Kinetics of absorption changes in the interaction of (I) $\left(1.5 \cdot 10^{-4} \mathrm{M}\right)$ with GSH $\left(10^{-3} \mathrm{M}\right)$ : spectra were registered at $45 \mathrm{~s}$ (1), $5 \mathrm{~min}$ (2), and $20 \mathrm{~min}$ (3) after start of reaction. Spectra 4-18 were registered further with interval $20 \mathrm{~min}$. Spectra 19-28 were registered at $7.3(19), 9.4(20), 11.8(21), 13.8$ (22), 16.3 (23), 19.5 (24), 21.5 (25), 22.8 (26), 23 (27), and 24 (28) h after start of reaction. Conditions of reaction: $25^{\circ} \mathrm{C}$, solvent is $0.05 \mathrm{M}$ Tris- $\mathrm{HCl}$ buffer, $\mathrm{pH}$ 7.0. Spectra 1-28 have 2 maxima: $\lambda_{1}=315 \mathrm{~nm}$ and $\lambda_{2}=367 \mathrm{~nm}$. The inset shows kinetics of (II) accumulation at interaction of (I) with GSH on the base of the experimental data shown on this figure. Circles are the experimental data. Approximation (theoretical curve) was made by means of $y(t)=y_{0}+A \cdot e^{-k t}$. (I) is the complex $\left[\mathrm{Fe}_{2}\left(\mathrm{SC}_{5} \mathrm{H}_{11} \mathrm{NO}_{2}\right)_{2}(\mathrm{NO})_{4}\right] \mathrm{SO}_{4} \cdot 5 \mathrm{H}_{2} \mathrm{O}$, and (II) is the complex $\left[\mathrm{Fe}_{2}\left(\mathrm{SC}_{10} \mathrm{H}_{17} \mathrm{~N}_{3} \mathrm{O}_{6}\right)_{2}(\mathrm{NO})_{4}\right] \mathrm{SO}_{4} \cdot 2 \mathrm{H}_{2} \mathrm{O}$.

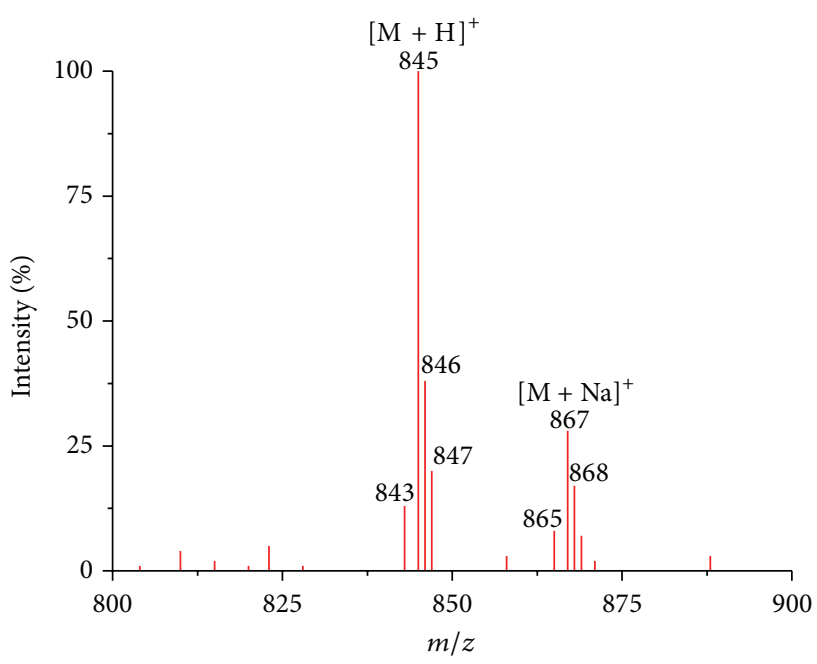

FIgURE 9: Mass spectrum (I) + GSH (as in experiment, shown in Figure 8 ) after $24 \mathrm{~h}$ from the start of the reaction: (ESI, $+4.5 \mathrm{kV})$. (I) is the complex $\left[\mathrm{Fe}_{2}\left(\mathrm{SC}_{5} \mathrm{H}_{11} \mathrm{NO}_{2}\right)_{2}(\mathrm{NO})_{4}\right] \mathrm{SO}_{4} \cdot 5 \mathrm{H}_{2} \mathrm{O}$. M is the cation of (II).

absorption spectra by the least square method using program MathCad.

\section{References}

[1] L. J. Ignarro, Nitric Oxide: Biology and Pathobiology, Academic Press, San Diego, Calif, USA, 2000. 
[2] J. A. McCleverty, "Chemistry of nitric oxide relevant to biology," Chemical Reviews, vol. 104, no. 2, pp. 403-418, 2004.

[3] A. R. Butler and I. L. Megson, "Non-heme iron nitrosyls in biology," Chemical Reviews, vol. 102, no. 4, pp. 1155-1165, 2002.

[4] K. Szaciłowski, A. Chmura, and Z. Stasicka, "Interplay between iron complexes, nitric oxide and sulfur ligands: structure, (photo)reactivity and biological importance," Coordination Chemistry Reviews, vol. 249, no. 21-22, pp. 2408-2436, 2005.

[5] T.-T. Lu, H.-W. Huang, and W.-F. Liaw, "Anionic mixed thiolate- sulfide-bridged roussin's red esters $\left[(\mathrm{NO})_{2} \mathrm{Fe}(\mu\right.$-SR $)(\mu$ $\left.\mathrm{S}) \mathrm{Fe}(\mathrm{NO})_{2}\right]^{-}(\mathrm{R}=\mathrm{Et}, \mathrm{Me}, \mathrm{Ph})$ : a key intermediate for transformation of dinitrosyl iron complexes (DNICs) to [2Fe-2S] clusters," Inorganic Chemistry, vol. 48, no. 18, pp. 9027-9035, 2009.

[6] C. E. Tinberg, Z. J. Tonzetich, H. Wang et al., "Characterization of iron dinitrosyl species formed in the reaction of nitric oxide with a biological Rieske center," Journal of the American Chemical Society, vol. 132, no. 51, pp. 18168-18176, 2010.

[7] H. Lewandowska, M. Kalinowska, K. Brzóska, K. Wójciuk, G. Wójciuk, and M. Kruszewski, "Nitrosyl iron complexessynthesis, structure and biology," Dalton Transactions, vol. 40, no. 33, pp. 8273-8289, 2011.

[8] B. C. Sanders, A. K. Patra, and T. C. Harrop, "Synthesis, properties, and reactivity of a series of NonHeme $\{\mathrm{FeNO}\} 7 / 8$ complexes: implications for Fe-Nitroxyl coordination," Journal of Inorganic Biochemistry, vol. 118, pp. 115-127, 2013.

[9] N. A. Sanina and S. M. Aldoshin, "Structure and properties of iron nitrosyl complexes with functionalized sulfur-containing ligands," Russian Chemical Bulletin, vol. 60, pp. 1223-1251, 2011.

[10] N. A. Sanina, O. S. Zhukova, S. M. Aldoshin, N. S. Emel'yanova, and G. K. Gerasimova, "Application of iron tetranitrosyl complex with thiophenol as antitumor drug," Patent RU 2429242. 2011.

[11] N. A. Sanina, K. A. Lysenko, O. S. Zhukova, T. N. Roudneva, N. S. Emel'yanova, and S. W. Aldoshin, "Water-soluble binuclear nitrosyl iron complexes with natural aliphatic thiolyls possessing cytotoxic, apoptotic and NO donor activity," Patent US 8, 067, 628 B2, 2011.

[12] N. Y. Giliano, L. V. Konevega, L. A. Noskin, V. A. Serezhenkov, A. P. Poltorakov, and A. F. Vanin, "Dinitrosyl iron complexes with thiol-containing ligands and apoptosis: studies with HeLa cell cultures," Nitric Oxide, vol. 24, no. 3, pp. 151-159, 2011.

[13] N. A. Sanina, L. I. Serebryakova, N. S. Shul'zhenko, O. I. Pisarenko, T. N. Roudeva, and S. M. Aldosin, "Application of iron binuclear complex sulphur-nitrosyl complex of the anionic type as a vasodilative drug".

[14] N. A. Sanina, K. A. Lysenko, O. S. Zhukova, T. N. Rudneva, N. S. Emel'janova, and S. M. Aldosin, "Water soluble binuclear cation nitrosyl iron complexes with natural aliphatic thiolyls processing cytotoxic, apoptotic and NO-donor activity," Patent RU 2441873 C2, 2006.

[15] A. F. Vanin, V. I. Lozinskii, and V. I. Kapel'ko, "Polymeric composition for the preparation of the stabilize form of the dinitrosyl iron complex the method of it synthesis," Patent RU, 2291880 C1, 2007.

[16] A. F. Vanin and E. I. Chazov, "Prospects of designing the medicines with diverse therapeutic activity on the dasis of dinitrosyl iron complexes with thiol-containing ligands," Biofizika, vol. 56, no. 2, pp. 304-315, 2011.

[17] N. A. Sanina, L. A. Syrtsova, N. I. Shkondina et al., "Reactions of sulfur-nitrosyl iron complexes of " $\mathrm{g}=2.03$ " family with hemoglobin ( $\mathrm{Hb})$ : kinetics of $\mathrm{Hb}-\mathrm{NO}$ formation in aqueous solutions," Nitric Oxide, vol. 16, no. 2, pp. 181-188, 2007.

[18] N. A. Sanina, G. V. Shilov, S. M. Aldoshin et al., "Structure of the binuclear tetranitrosyl iron complexes with a pyrimidin-2yl ligand of the $\mu_{2}$-S type and the $\mathrm{pH}$ effect on its NO-donor ability in aqueous solutions," Russian Chemical Bulletin, vol. 58, no. 3, pp. 572-584, 2009.

[19] A. A. Timoshin, T. S. R. Orlova, A. F. Vanin et al., "Dinitrosyl iron complexes, a new type of hypotensive drugs," Russian Chemical Journal, vol. LI, no. 1, pp. 88-92, 2007.

[20] N. A. Sanina, O. S. Zhukova, Z. S. Smirnova, L. M. Borisova, M. P. Kiseleva, and S. M. Aldoshin, "The antitumor activity of nitrosyl iron complexes, of a new class of nitric oxide donors," Russian Biotherapeutic Journal, no. 1, pp. 52-58, 2008.

[21] N. A. Sanina, New class of nitric monoxide donors: structure and properties of nitrosyl iron complexes with functional sulphur containing ligands [Ph.D. thesis], Institute of Problems of Chemical Physics, Chernogolovka, Russia, 2011.

[22] D. M. Townsend, K. D. Tew, and H. Tapiero, "The importance of glutathione in human disease," Biomedicine and Pharmacotherapy, vol. 57, no. 3, pp. 145-155, 2003.

[23] P. M. Chumakov, "Versatile functions of p53 protein in multicellular organisms," Biochemistry, vol. 72, no. 13, pp. 1399-1421, 2007.

[24] N. A. Sanina, L. A. Syrtsova, N. I. Shkondina, E. S. Malkova, A. I. Kotelnikov, and S. M. Aldoshin, "Hemoglobin-stabilized tetranitrosyl binuclear iron complex with pyridine-2-yl in aqueus solutions," Russian Chemical Bulletin International Edition, vol. 56, no. 4, pp. 761-766, 2007.

[25] X. Zhang and M. P. Broderick, "Amperometric detection of nitric oxide," Modern Aspects of Immunobiology, vol. 1, no. 4, pp. 160-165, 2000.

[26] A. M. Miles, D. A. Wink, J. C. Cook, and M. B. Grisham, "Determination of nitric oxide using fluorescence spectroscopy," in Methods in Enzymology, L. Packer, Ed., vol. 268, part A, pp. 105121, Academic Press, New York, NY, USA, 1996. 

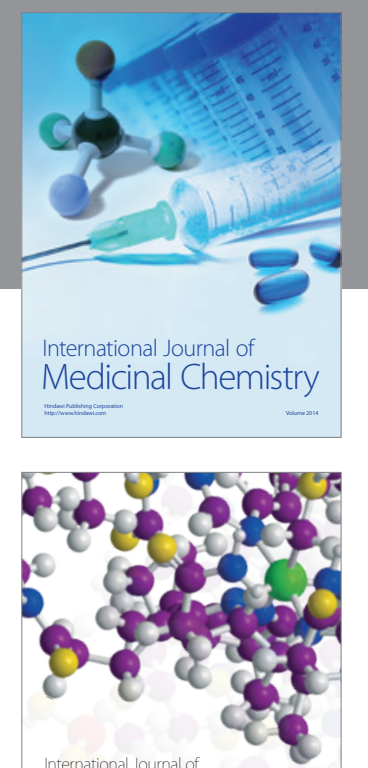

\section{Carbohydrate} Chemistry

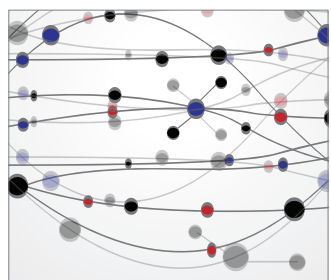

The Scientific World Journal
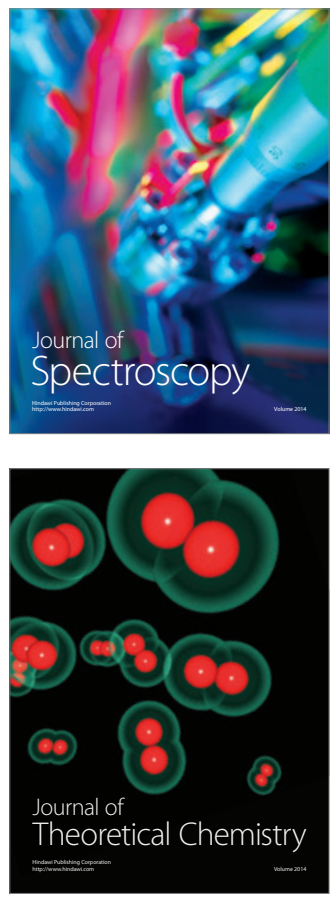
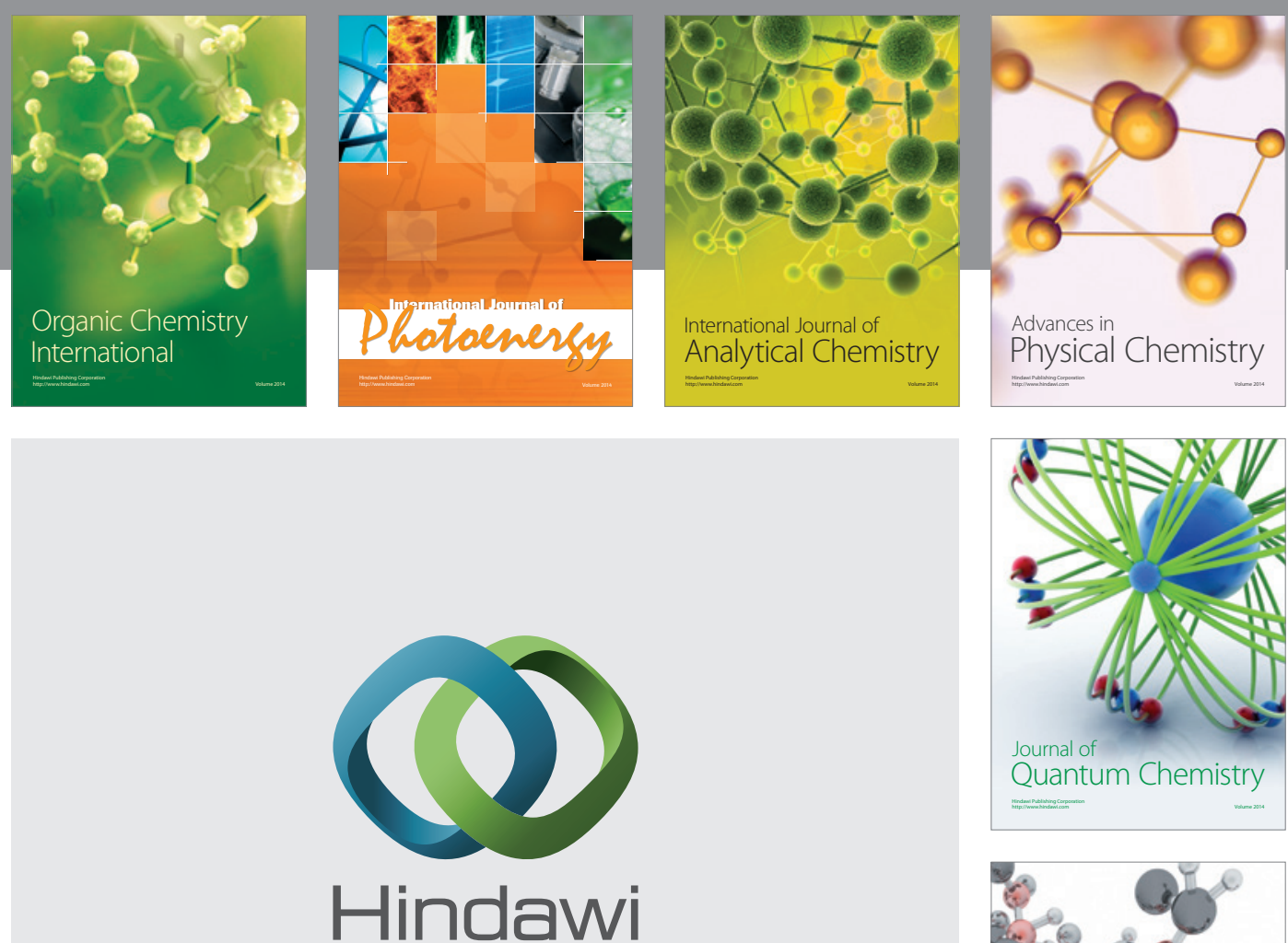

Submit your manuscripts at

http://www.hindawi.com

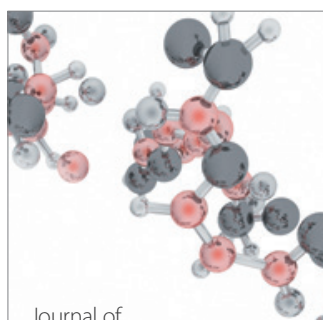

Analytical Methods

in Chemistry

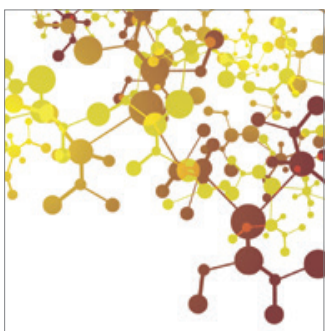

Journal of

Applied Chemistry

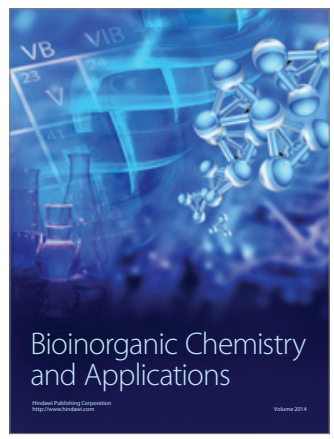

Inorganic Chemistry
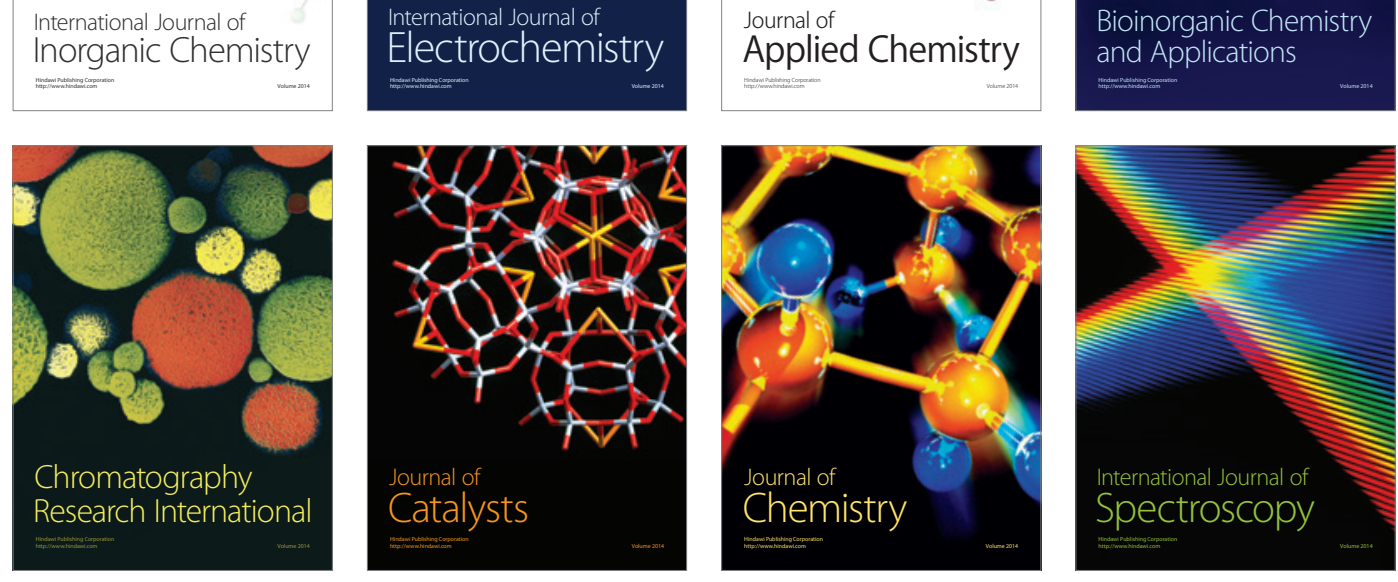